\title{
DRD2 Gene Mutation
}

National Cancer Institute

\section{Source}

National Cancer Institute. DRD2 Gene Mutation. NCI Thesaurus. Code C126835.

A change in the nucleotide sequence of the DRD2 gene. 